\title{
LEGAL ASPECTS OF THE MANNERS OF HOLDING SHAREHOLDERS' ASSEMBLIES IN THE CONDITIONS OF COVID 19 PANDEMIC
}

\author{
Jordan DELEV \\ PhD, Assistant Professor, International Vision University, Faculty of Law \\ E-mail: jordan.delev@vizyon.edu.mk
}

\section{Milena NAJDOVA}

$\mathrm{PhD}$, National Bank of the Republic of North Macedonia

E-mail: deleva_milena@hotmail.com

\begin{abstract}
The functioning of the world social and economic order in the $21 \mathrm{st}$ century has faced many challenges, but the global Covid-19 pandemic has caused unpredictable tendencies that require immediate, effective and adequate reactions that will respond seriously to the new situation. No society, including Macedonia, has remained immune to the consequences caused by this pandemic, penetrating deeply into all segments of society. The Covid-19 pandemic directly raised the question of the readiness of national socio-economic orders to function in digital format. The functioning of the main carriers of economic fluctuation, i.e., business entities and their capacity for digitalization, is one of the main preoccupations imposed by the pandemic. These issues are current in global and Macedonian aspects. The main purpose of this paper is, through analysis of the practice of joint stock companies listed on the Macedonian Stock Exchange and those with special reporting obligations, to identify the degree of utilization of the opportunity provided in the Law on Trade Companies for organization at shareholders' assemblies by electronic means during the conditions of the pandemic. At the same time, the paper concentrates on the effects that the pandemic causes in the realization of the shareholder rights under the newly created conditions. In addition to analyzing the current situation, the paper provides guidance for improving the provisions for the organization of shareholders' assemblies by electronic means and the exercise of shareholders' rights.
\end{abstract}


Keywords: Joint stock companies, shareholders' assemblies by electronic means, shareholders' rights, COVID 19 pandemic

\section{Introduction}

Global and national social systems are facing a global health crisis that has social, economic and legal consequences. Although the Covid-19 pandemic primarily manifests its health implications, it deeply expresses its impact on world and national economies, creating a new economic crisis. The impact is directly felt by the business units, the companies whose normal functioning is increasingly dependent on digitalization as a basic precondition for easier control of the situation imposed by Covid-19. Analyzed from the perspective of companies and corporate governance, the crisis caused by Covid-19 is significantly different from the previous economic crises that emerged in the $21^{\text {st }}$ century. Previous crises have stemmed from corporate misconduct, falsification of accounting data, risk-taking and greed of top management. At the same time, they were partially enabled by poor regulation and its inconsistent application. As a result, this stimulated changes in company law and corporate governance codes to strengthen company control and increase sanctions in case of non-compliance. (Zattoni \& Pugliese, 2021, p. 1405) In contrast, the crisis caused by Covid-19 is neither due to misbehavior of companies, nor is it a consequence of shortcomings in control systems. It is therefore unlikely to provoke regulatory interventions affecting corporate governance mechanisms in a similar way to previous crises, but merely anticipating measures for efficient and smooth functioning in the context of the Covid-19 crisis. (Gelter \& Puaschunder, 2021, p. 6)

In the Republic of North Macedonia (RNM) the first case of Covid-19 infection was registered on February 26, 2020. In a short period of time, since the registration of the first contagious case, at the proposal of the government of RNM on March 18, 2020, in order to more successfully deal with the pandemic, the President of RNM declared a state of emergency on the territory of the entire Republic. The onset of the state of emergency is taken as a starting point in our research and covers the period from March 20, 2020 to May 20, 2021.

The real impact of Covid-19 on corporate governance, both internationally and domestically, has yet to be determined. But there is no doubt that the pandemic has slowed down the basic means by which joint stock companies operate and has important implications for the organization of shareholders' assemblies and the realization of their shareholder rights. (OECD, 2020 , p. 7) The concentration of this paper is on the organization of shareholders' assemblies in conditions of a pandemic by the Macedonian joint stock companies listed on the Macedonian Stock Exchange Inc. Skopje. It primarily provides an overview of the national legal framework governing the convening and holding of shareholders' assemblies and the degree of compliance with European standards. The legally prescribed shareholder rights are also a subject of observation of this paper, which seeks to provide guidance 
Legal aspects of the manners of holding shareholders' assemblies...

on how such performance can be improved and upgraded, and how the rules of good cooperative governance would be applied in a pandemic.

\section{The Legal Framework for Convening a Shareholders' Assembly in the Republic of North Macedonia}

The organizational hierarchy of the Macedonian joint stock companies places the assembly of shareholders at the very top, as a body that has a central place in the structure of the joint stock company. The legal framework that determines the competencies, convening and holding of the shareholders' assembly is defined by the Law on Trade Companies (LTC).

The elevated hierarchical position of the assembly is a result of the competencies that fall within its scope of work, which include: amendment of the statute; approval of the annual account, the financial statements and the annual report on the operation of the company for the previous business year and deciding on the distribution of the profits; election and dismissal of the members of the board of directors and members of the supervisory board; approval of the operation and management of the company's operation by the members of the management body and the supervisory board; amendment of the rights attached to particular types and classes of stocks; increasing or decreasing the company's basic capital; issuing stocks and other securities; appointment of the authorized auditor to audit the annual account and other financial statements, if the company is obliged to prepare them; transformation the company into another type of company, as well as reorganization of the company and termination of the company. (LTC, $2004 \&$ rev. 2020, art. 383)

The annual assembly is convened by the management body no later than three months after the composition of the annual account, the financial statements and the annual report of the company for the previous business year, and not later than six months from the end of the calendar year or 14 months from holding the last annual assembly. The discussion and approval of the work of the management body / the supervisory board, i.e. the manner of conducting the operation of the company must be related to the discussion of the annual account, financial statements and the annual report on the operation of the company for the previous business year.

In the organizational structure of the joint stock company, the assembly assumes the position of guarantor of the operation of the company, based on the principles of effectiveness and accountability, since through it the shareholders are informed of the current position of the company. In that direction, the procedure for its convening is subject to fulfillment of the criteria of publicity in the operation. When the interests of the company and the shareholders so require, an assembly may be convened between two annual assemblies. The management body, the supervisory board, i.e. the nonexecutive members of the board of directors may, by a majority vote of their members, when it is provided by the LTC, on their own initiative or at the request of a shareholder, decide to convene an assembly. The Law also provided for the possibility for the shareholders who have at least one tenth of 
all voting shares to be able to submit a request for convening an assembly to the management body at the head office of the company. Within a certain period (eight days from the day of receipt of the request), the management body should decide whether to accept or reject the request. If a decision is made to reject the request, the reasons for the decision must be stated. If upon the request of the shareholders who have a majority of all voting shares, the management body, i.e. the supervisory board, does not convene an assembly within 24 hours from the day of submitting the request, the shareholders may submit a proposal for convening an assembly to the court. (LTC, $2004 \&$ rev. 2020, art. 385) This provision limits the power of the management body, i.e. the supervisory board, and protects the right of the shareholders who have a majority of all voting shares to convene a shareholders' assembly through a court procedure, if they consider that their interests and interests of the company so require.

The convening of an assembly on the basis of a court decision is based on the assumption that, if the management body, the supervisory board, i.e. the non-executive members of the board of directors do not make a decision within the legally determined deadline or do not accept the request for convening an assembly, the court can upon a proposal adopt a decision for convening the assembly. The court, within eight days from the day of submitting the proposal, shall adopt a decision for convening an assembly if the conditions, manner and procedure for convening an assembly, determined by the LTC, are met and if the issues proposed for the agenda, according to this law or according to the statute are in the competence of the assembly. In the decision to convene the assembly, the court orders the convening of the assembly and taking specific actions necessary to achieve the purposes for which the assembly is convened, including the appointment of a person to convene the assembly. The person appointed by the court submits requests to the joint stock company listed on the stock exchange, i.e. the company which in accordance with the Law on Securities (LS) has special reporting obligations of the convening of the assembly on the official website of the company and the official web page of the stock exchange wherein the shares of the company are listed, as well as the other necessary actions for successful convening and holding of a session of the assembly of the company. The joint stock company and the stock exchange have two duties: 1) without delay and in time to fulfill all the necessary requirements in accordance with the provisions of the LTC, shall convene a session of the assembly and 2) the person convening the assembly shall announce the convening online. ${ }^{1}$

According to the legal provisions, the assembly can be convened by invitation of the shareholders or by public announcement. The assembly is convened by sending an invitation to all shareholders whose shares entitle them to participate in the operation of the assembly that is being convened. The invitation is sent according to the excerpt from the shareholder book, which is not older than three days until the day of sending the invitation.

\footnotetext{
${ }^{1}$ It is envisaged that the person undertaking the actions for convening an assembly will be able to use legal services.
} 
The second manner is by public announcement for holding a session of the assembly on half a page in at least one daily newspaper that is published on the entire territory of the RNM. With the amendments to the Law, new liabilities have been introduced for the company whose shares are listed on the stock exchange and which, in accordance with the LS, has special reporting obligations: the content of the public announcement must be published on the cover page of its official website, and if the shares are listed on the stock exchange, it is obliged to submit the content of the public announcement to the stock exchange to be published on the stock exchange website. If a company whose shares are listed on a stock exchange and a company that in accordance with the LS has special reporting obligations on its official website does not publish the above data, it will be fined in the amount of 2,500 to 5,000 euros in denar counter value. (LTC, 2004 \& rev. 2020, art. 605-a)

According to the definition given in the LS, a joint stock company with special reporting obligations is a company that: a) has made a public offering of securities; or b) has a share capital of EUR 1,000,000 in denar counter value and more than 50 shareholders; or c) is listed on the stock exchange. (LS, 2005 $\&$ rev. 2020, art. 2 (1 (2)) These conditions are alternative, not cumulative. It is enough that only one of these conditions is met for the joint stock company to be considered as a joint stock company with special reporting obligations. The number of shareholders in these companies is usually very large and the economic and financial power of the joint stock company is significant, given their substantial impact on the market of goods, services, capital and labor.

A legal inconsistency can be seen in the Macedonian legislation in that most of the obligations for disclosure of information by these companies are prescribed in the LS while the provisions governing the convening and holding of the assembly of companies with special reporting obligations are prescribed in LTC.

In the LTC, with regard to the joint stock companies with special reporting obligations and their convening of the assembly, in principle the same provisions apply to the joint stock companies in general, with specific provisions for the content of the invitation / public announcement being determined. In the public announcement / invitation for holding a session of the assembly of a company whose shares are listed on the stock exchange, i.e. session of the assembly of a company which in accordance with the LS has special reporting obligations, the date and time of the session are indicated, the location of the session is stated and the proposed agenda of the session of the assembly is attached.

The public announcement / the invitation for holding a session of the assembly also contains a description of the procedures according to which the shareholders participate and vote at a session of the assembly, especially for: a) how the shareholders can include items on the agenda of the assembly and propose decisions with information on how they can do the same after the invitation is delivered to them or after the announcement is published, how the shareholders can ask questions to the company about the items from the agenda of the session of the assembly, with information about the deadline by which 
they can do this, alternatively (as an exception) the public announcement / the invitation can contain only the last deadlines by which the shareholders can propose items on the agenda, set questions or to propose decisions if the invitation / the public announcement lists the official website of the company with a reference on which can be found detailed information on the manner of proposing items on the agenda, asking questions and proposing decisions by to shareholders; b) how the representative voting procedure takes place, how the representative voting forms will be made available to the shareholders when the company has prepared such forms and information on how the company is ready to receive electronic notifications from the shareholders for given authorizations to representatives and c) how the voting procedure takes place by correspondence or electronically when the company enables such voting.

In the public announcement / invitation for holding a session of the company's assembly, the address of the official website of the company should be stated, where the information that should be published on it during the convening of a session of the company's assembly should be available. (LTC, $2004 \&$ rev. 2020, art. 388-a) If the company acts contrary to these legal provisions, i.e. commits a misdemeanor, it will be fined in the amount of 2,500 to 5,000 euros in denar counter value.

This is where the increased insistence of the legislation for greater transparency and reporting can be seen, followed by increased publication of information regarding the convening of the session of the assembly of the company whose shares are listed on the stock exchange, i.e. with special reporting obligations. In a period that cannot start later than the twenty-first day before the day of the session of the company's assembly, as well as on the day of the session of the assembly, that means 22 days before the day of the session, the company must publish at least the following information: 1) the content of the public announcement / the invitation for convening a session of the company's assembly; 2) the total number of stocks and the total number of voting rights arising from the stocks with voting rights on the day of publication of the public announcement, that is the day of sending the invitation, including the total number of each type and class; 3 ) documents and materials that are to be reviewed on the session of the company's assembly; 4) proposed decision that are to be adopted or when such decisions are not proposed, opinions from an authorized body or a company's body on each point from the proposed agenda of the session of the company's assembly; 5) proposed decisions of the stockholders of the company that need to be published by the company immediately upon their receipt, and 6) the forms for voting via representative or the forms for voting via correspondence prepared for electronic take over by the stockholders. In case the company does not make available the forms for electronic take over on the its web page, then the company shall on the same page publish how can be received in written form and on personal expanse, and upon a request of the stockholders shall deliver the forms. (LTC, $2004 \&$ rev. 2020, art. 388-b) If a company whose shares are listed on a stock exchange and a company which in accordance with the LS has special reporting obligations 
does not publish the above data on its official website, it will be fined in the amount of 2,500 to 5,000 euros in denar counter value.

The notifications related to the sessions of the shareholders' assembly of the companies whose shares are listed on the stock exchange have their treatment in the Listing Rules of the Macedonian Stock Exchange which provide identical reporting obligations as the LTC, thus elaborating and adjusting them in detail to the needs of listed companies for the purpose of increased reporting. According to these Rules, issuers ${ }^{2}$ from all sub-segments of the securities market ${ }^{3}$ are obliged to publicly announce the call for a shareholders' assembly at least 21 days before the day of holding. Additionally, the issuers from all sub-segments are obliged to publish the public announcement for holding a shareholders' assembly on the front page of their official website, in at least one daily newspaper in the RNM as well as on the website of the stock exchange through SEI-NET ${ }^{4}$. If an issuer from any subsegment publicly announces the convening of a shareholders' assembly in a daily newspaper or on its official website, and does not publish it through SEINET, the stock exchange may itself make the announcement. Issuers whose shares are listed in the Super Listing and Stock Exchange Listing sub-segments are obliged to publish the content of the draft decisions, if they are listed as items on the agenda in the published public announcement for the session of the shareholders' assembly. If the content of the draft decisions is not published together with the public announcement for the session of the shareholders' assembly, in the period from the announcement of the public announcement until the announcement of the content of the draft decisions, the stock exchange will temporarily suspend trading in the company shares. In addition, the Listing Rules stipulate for these issuers obligation to publish the complete materials for the shareholders' assembly at least seven days before the day of the shareholders' assembly. On the other hand, the issuers from all sub-segments are obliged to publish all changes and amendments to the agenda of the shareholders' assembly immediately after their publication on the front page of their official website and in at least one daily newspaper in the RNM. These issuers are obliged to publish the content of the decisions no later than the

\footnotetext{
2 There is a terminological difference between the LTC and the Listing Rules of the Macedonian Stock Exchange, which use the name issuer to denote a company, the Republic of North Macedonia, a state institution, a public enterprise, a local selfgovernment unit and the National Bank of the Republic of Northern Macedonia which securities are traded on the stock exchange.

3 The securities market means two market segments: "Official Market", which is a market of listed securities, divided into Super Listing, Stock Exchange Listing, Mandatory Listing and Listing of Small Joint Stock Companies (sub-segments); and "Regular Market", which is a market of unlisted securities, divided into a market of joint stock companies with special reporting obligations and a "Free Market".

${ }^{4}$ SEI-NET means the electronic information system of the listed companies, through which the issuer publishes all price sensitive information and announcements. The announcements published on the SEI-NET Stock Exchange make them available to the public.
} 
beginning of trading on the first trading day after the day of their adoption by the shareholders' assembly, if they were adopted at a session of the shareholders' assembly. If the issuers whose shares are listed in the Super Listing and Stock Exchange Listing sub-segments do not publish the content of the above, the stock exchange will temporarily suspend trading in the shares of the company. Additionally, the issuers from all sub-segments are obliged to publish the decisions made by the shareholders' assembly and the annual report, except for the already determined decisions for which a different publication deadline is required, within seven days after the adoption by the shareholders' assembly. (Listing Rules, 201, art. 39)

Informing the shareholders of the formal and content aspects of the assembly is done through precisely defined mechanisms, submitting and receiving materials and other information. If the LTC and the statute stipulate that reporting, i.e. delivery of material and other information from the company to the shareholders and to the company, it must be done by registered mail, telegram, fax, e-mail or daily newspaper. (LTC, $2004 \&$ rev. 2020, art. 389)

The participation of the shareholders in a session of the assembly by electronic means (electronic assembly) at a company whose shares are listed on a stock exchange, i.e. a company with special reporting obligations, is another specificity that refers to these companies whose technical equipment should be in function of facilitation of the realization of shareholder rights. This opportunity is in line with the growing trend of digitalization in the operations of joint stock companies and, especially popular in the period of Covid-19 crisis, where the operation through electronic communication media became a necessary tool for normalization of working conditions. The assembly of the company by electronic means can be held if the shareholders are provided with at least one of the following ways to participate in the session of the assembly of the company by electronic means: 1) direct transmission of the assembly; 2) two-way audio and video communication in live, enabling the stockholders to address the assembly from any remote location, and 3) electronic means for voting, before or during the assembly without the need to authorize a representative who would attend the session.

In order to participate in such an assembly, the company must have established a system for electronic registration and recording of the stockholders for the purpose of their identification and preservation of electronic security during the participation of the stockholders at an assembly by electronic means and shall not require the stockholders to submit documents verified by a notary or verified by another domestic or foreign authorized authority. These companies are obliged to provide, at their own expense, an authorized court translator from Macedonian to English and from English to Macedonian where shareholders who are not citizens of the RNM have announced their participation in an assembly. However, it is not stated to whom the presence should be announced, nor in what period before the session. (LTC, $2004 \&$ rev. 2020, art. 391-a) 
Legal aspects of the manners of holding shareholders' assemblies...

\section{The Degree of Harmonization of the Macedonian Legal Framework for Convening a Shareholders' Assembly with the Legislation of the European Union}

RNM, as a candidate for membership in the European Union (EU), strives to harmonize its legislation with EU legislation. For that purpose, the convening, holding and organization of the shareholders' assembly regulated by the LTC must be in correlation with the norms provided by Directive 2007/36/EC of 11 July 2007 on the exercise of certain rights of shareholders of listed companies, which defines the framework of the functioning of the shareholders' assemblies in the member states of the Union.

Directive 2007/36 / EC establishes the criterion of equal treatment of shareholders, which is the basis of corporate governance. The criterion requires the company to provide equal treatment for all shareholders who are in the same position in terms of participation and voting rights at the general meeting. (Renneboog \& Szilagyi, 2013, p. 315-323) The information that should be published before the general meetings is especially prominent. It is the starting point for quantifying the observance of the mandatory and optional standards of corporate governance. Without prejudice to the provisions arising from takeover bids, Member States shall ensure that the companies announce the convening of the general meeting in one of the statutory manners, no later than the twenty-first day before the date of the meeting. (Directive 2007/36/EC, art. 5 (1)) Thus ensuring prompt access and non-discrimination. Companies are also required to use media outlets that can be trusted to effectively disseminate information to the public across the EU. Notice of convening a general meeting includes: a) exact indication of the time and place where the general meeting will be held, as well as the proposal of the agenda of the general meeting; b) a clear and precise description of the procedures that the shareholders have to follow in order to participate and vote at the general meeting. These include information on shareholders' rights; the procedure for voting by proxy, especially for the forms used for voting by proxy and the means through which the company can receive electronic notification for the appointment of a proxy; and where appropriate, voting procedures for casting votes by correspondence or by electronic means; c) where applicable, the date of determination of the status in the book of shareholders and explanation that only those who are shareholders on that date will have the right to participate and vote at the general meeting; d) indication where and how the full, unabridged text of the documents and draft resolutions may be obtained; e) the address of the website where the information will be available. (Directive 2007/36/EC, art. 5 (2) (3))

In a continuous period from the twenty-first day before the day of the general meeting and including the day of the meeting, the company, in any case, shall make available to its shareholders on its website the following information: (a) the convocation; (b) the total number of shares and voting rights at the date of the convocation (including separate totals for each class of shares where the company's capital is divided into two or more classes of shares); (c) the documents to be submitted to the general meeting; (d) a draft 
resolution or, where no resolution is proposed to be adopted, a comment from a competent body within the company, to be designated by the applicable law, for each item on the proposed agenda of the general meeting; moreover, draft resolutions tabled by shareholders shall be added to the website as soon as practicable after the company has received them; (e) where applicable, the forms to be used to vote by proxy and to vote by correspondence, unless those forms are sent directly to each shareholder. (Directive 2007/36/EC, art. 5 (4))

Following the latest achievements in the field of information technology, the European legislation is adapted to the modern manners of communication and therefore envisages participation and decision-making in the general meeting electronically or by correspondence. (Siems, 2008, p. 222) Modern European legislation allows companies to offer their shareholders any form of participation in the general meeting by electronic means, especially in one or all of the following forms of participation: a) real-time transmission of the general meeting; b) real-time two-way communication enabling shareholders to address the general meeting from a remote location; c) a mechanism for casting votes, whether before or during the general meeting, without the need to appoint a proxy holder who is physically present at the meeting. The use of electronic means for the purpose of enabling shareholders to participate in the general meeting may be made subject only to such requirements and constraints as are necessary to ensure the identification of shareholders and the security of the electronic communication, and only to the extent that they are proportionate to achieving those objectives. This is without prejudice to any legal rules which Member States have adopted or may adopt concerning the decision-making process within the company for the introduction or implementation of any form of participation by electronic means. (Directive 2007/36/EC, art. 8)

This European company law must be reflected in the Macedonian company law and requires changes in the LTC in order to achieve the expected harmonization of the legislations. The general conclusion is that the Macedonian company law is largely harmonized with the European directives in this area. This is confirmed by the Report on North Macedonia for 2020 of the European Commission where it is noted that RNM has a good level of readiness in the field of company law. The country is making good progress following $\mathrm{EU}$ rules on formation, registration, merger and division of companies. It is emphasized that some progress has been made in the further harmonization of the LTC with the EU legislation. (EU, European Commission, 2020, p. 66)

\section{Holding Shareholders' Assemblies and Exercising Shareholder Rights in the Republic of North Macedonia in Conditions of Covid-19 Pandemic}

For almost all joint stock companies in RNM, Covid-19 has created many challenges. The shareholders' assembly in the newly created conditions is focused on the long-term sustainability of the company and its business prospects. The Covid-19 pandemic has brought significant obstacles to the 
Legal aspects of the manners of holding shareholders' assemblies...

organization and holding of annual shareholders' assemblies. Despite severe restrictions on holding public meetings, the legal requirement to hold an annual shareholders' assembly remained. This situation forced the listed joint stock companies to restart and reorganize their activities related to holding a shareholders' assembly.

In this regard is the announcement to the public of the Securities and Exchange Commission which, guided by the undertaken necessary measures and activities to ensure protection of citizens' health and ensure continuity of business processes, has issued recommendations to authorized market participants. Among the mentioned recommendations is the recommendation addressed to the joint stock companies to modify the usual planning for holding the annual shareholders' assembly given the measures to prevent the spread of Covid-19. In the case of already scheduled assemblies, if technically possible, to consider the option of a virtual assembly or participation by written correspondence. If holding assemblies with "physical" presence is an inevitable solution, measures should be taken to limit the risk to those present, i.e. to consolidate the presence and voting of the assembly with as few people as possible (taking into account the relevant quorums for session and decisionmaking) through representatives. (Securities and Exchange Commission, 2020) The recommendation issued by the Securities and Exchange Commission is not binding. Macedonian joint stock companies should organize the annual meetings during the Covid-19 pandemic by choosing one of the means provided in the LTC.

In the research period, i.e. since the declaration of a state of emergency on the entire territory of RNM, starting from March 20, 2020 until May 20, 2021, the focus has been on those joint stock companies listed on the Macedonian Stock Exchange Inc. Skopje, i.e. those with special reporting obligations according to LC. During this period, a total of 195 public announcements for convening a shareholders' assembly were published on the website of the stock exchange, through SEI-NET. From the published public announcements, it can be concluded that the majority of joint stock companies in RNM have approached the traditional manner of organizing a shareholders' assembly with physical presence. Out of 195 public announcements for convening an assembly, 175 public announcements envisage physical presence of the shareholders at the annual assembly. Out of 175 public announcements in which it is envisaged to organize an assembly in the traditional manner, only in 38 public announcements was an alternative possibility noticed for the voting of the assembly to be performed through written correspondence. Whereas, out of 175 published public announcements that provide for the physical presence, only in two public announcements was an alternative possibility of electronic voting noticed. These two announcements are published by the same joint stock company, one for convening a shareholders' assembly in 2020, and the other in 2021. On the other hand, among the published public announcements, there is a tendency for the shareholders' assemblies in this period to be organized without physical presence. This trend is observed only in 20 published public announcements out of a total of 195 published public announcements. In these 
20 published public announcements for organizing a shareholders' assembly without physical presence, the voting is foreseen to take place through written correspondence. In only one public announcement was organization of an assembly without physical presence envisaged, with, in addition to voting through written correspondence, the possibility to vote electronically was also provided. Summarized in the research period (20.03.2020 - 20.05.2021) from a total of 195 public announcements for convening a shareholders' assembly in 175 announcements, the physical presence of the shareholders of the assembly is proposed, and in 20 public announcements it is proposed that the shareholders' assembly will be takes place without physical presence. Written correspondence as an opportunity for voting at the shareholders' assemblies is provided in 58 public announcements, of which 38 provide written correspondence as an alternative together with physical presence, and in 20 public announcements where the organization of the assembly is without physical presence, possibility for mail-in voting or electronic voting is proposed. Electronic voting, as an opportunity to exercise the voting right of the shareholder is provided in only three public announcements for convening a shareholders' assembly.

\begin{tabular}{|c|c|c|c|c|}
\hline \multicolumn{5}{|c|}{$\begin{array}{c}\text { Organization of shareholders' assemblies of listed joint stock } \\
\text { companies in the Republic of North Macedonia in conditions of Covid- } \\
19 \text { pandemic } \\
\text { Research period }(\mathbf{2 0 . 0 3 . 2 0 2 0}-\mathbf{2 0 . 0 5 . 2 0 2 1 )}\end{array}$} \\
\hline $\begin{array}{l}\text { Total number of } \\
\text { published } \\
\text { public } \\
\text { announcements }\end{array}$ & $\begin{array}{l}\text { Holding a } \\
\text { shareholders' } \\
\text { assembly } \\
\text { with } \\
\text { physical } \\
\text { presence }\end{array}$ & $\begin{array}{l}\text { Holding a } \\
\text { shareholders' } \\
\text { assembly } \\
\text { without } \\
\text { physical } \\
\text { presence }\end{array}$ & $\begin{array}{l}\text { Voting by written } \\
\text { correspondence }\end{array}$ & $\begin{array}{l}\text { Electronic } \\
\text { voting }\end{array}$ \\
\hline 195 & 175 & 20 & 58 & 3 \\
\hline
\end{tabular}

It is noticeable that most of the published public announcements, $89.7 \%$, of the listed joint stock companies in conditions of Covid-19 pandemic, despite the recommendations for avoiding larger groupings and the recommendation of the Securities and Exchange Commission, envisage a traditional manner of organizing shareholders' assemblies with physical presence. Only $10.2 \%$ of the public announcements of the listed joint stock companies envisage organizing a shareholders' assembly without physical presence, where the voting would take place through correspondence. Correspondence voting is provided as an alternative in $29.7 \%$ of the published public announcements, and only in $1.5 \%$ is electronic voting provided as an option. This small percentage of utilization of modern informationtechnological achievements is based on the low popularity of these manners of organization, the low trust in these modern methods and the low degree of digitalization in the operation of the Macedonian joint stock companies. 
The exercise of shareholder rights is in no way subject to restrictions as a result of the Covid-19 pandemic. In the case of joint stock companies listed on the stock exchange, the exercise of the rights of the shareholders at the shareholders' assembly is regulated in a different way - in person or through attorneys or through electronic voting, monitoring of the assembly, voting by correspondence, the right to ask questions, participation in the assembly and the manner of determining the voting results. These mechanisms of exercising the rights of shareholders should be especially popularized in the new conditions caused by the pandemic. In order to effectively exercise the rights of shareholders, a number of mandatory obligations are prescribed for joint stock companies whose shares are listed on the stock exchange and which have special reporting obligations, such as establishing and using their own electronic systems or using the services of specialized companies, and the establishment of an official website on which they should continuously publish relevant information of interest to shareholders and stakeholders. (Kucera, Simala \& Noreuil, 2020)

The use of the traditional manner of organizing shareholders' assemblies with physical presence analyzed in accordance with the new efforts for increased shareholder activity, as a standard of good corporate governance, does not achieve the desired effect. Reduced shareholder activity is noticeable in the traditional shareholders' assemblies, which is characteristic for the period before the Covid-19 pandemic. The most common negative practices that are noticeable when holding shareholders' assemblies organized only with physical presence refer to: not giving enough instructions to use the opportunity to appoint an attorney and ask a question; limitations regarding the structure of the submitted questions; allowing only the possibility of sending a letter of attorney/questions by mail, and not by electronic means; not giving instructions on the set time frames to submit a letter of attorney/question; answering questions in groups, structured under one heading, with one generic answer, without allowing additional intervention or clarification by the shareholder; the choice by the companies not to answer all the questions. On the other hand, the practice of increased use of electronic means in the organization of shareholders' assemblies leads to increased transparency of the company and increased interest and greater activity of the shareholder in the operation of the assembly. Positive practices include: the possibility for the shareholders to send a letter of attorney/questions electronically on a special website or e-mail; determining the sufficient time of the shareholders (which in no way presupposes that the letter of attorney/questions must be submitted in advance) to be able to submit letter of attorney /questions properly; clear identification and definition of the basis on which the questions would be grouped; contacting any shareholder who has submitted similar questions to inform the shareholder that the questions will be grouped, but without excluding the obligation to provide written answers to individual questions on the website; publishing all questions and answers on the company's website immediately after the shareholders' assembly. 
Corporate practices used by companies that are extremely committed to promoting the principles of good corporate governance are moving in order to confirm the tendency that increased use of electronic means in the organization of shareholders' assemblies leads to increased shareholder activity. An appropriate example of practices that promote good corporate governance is the Marks and Spencer Group, which in 2020 organized a full virtual shareholders' assembly. Their shareholders could participate in the assembly through the Lumi platform, and, in terms of questions and votes, they could submit them in advance or for the duration of the assembly using a specially designed application or through the website. Marks and Spencer saw a huge increase in shareholder activity using the virtual method of organization, with over 1,500 people using their digital platform to vote, post questions or follow the broadcast. Compared to the previous year, when only 561 shareholders attended the physically organized shareholders' assembly. In 2020, more than 86 questions were asked at the assembly, which is an increase of 28 compared to the previous year, 13 questions were answered directly at the assembly, and the key topics raised were discussed with more than half of the total questions received. The questions that remained unanswered at the shareholders' assembly were published and answered on the company's website, and direct answers were also sent to the individual shareholders by the company's secretariat. Only 13 questions answered during the assembly at first seems to be too few, but it is a significant improvement given the fact that there was a time limit at organized assemblies with physical presence, which may mean that some questions remain unanswered. It is encouraging that the company strives to satisfy good corporate practices by answering all the questions and making the answers available to everyone, including those who did not attend the assembly. Unlike shareholders' assemblies with physical presence, additional issues face the possibility of remaining unheard attendees. The Marks and Spencer Shareholders Assembly in 2020 shows that virtual assemblies can result in increased shareholder activity. (Marks and Spencer Group, 2020, p. 184-185)

Good corporate practices that promote the active use of technological advances in combination with traditional methods in the normal functioning of joint stock companies are applied by companies that are aware that the digitalization of their operations is one of the natural processes they face. Pandemic conditions have only contributed to the emphasis on their necessity. The organization of the shareholders' assembly of Man Group plc, which in 2020 was organized in a hybrid manner shows how this direction is applied. The appointment of a proxy to vote was still required before the assembly could be held, but the full exercise of the right to ask questions and the obligation to respond was made possible by electronic means. The shareholders had access to the assembly through the WebEx platform, and the instructions for access to the platform were given through a statement published on the website of the stock exchange. All directors attended the assembly either in person or virtually, and although shareholders were unable to speak at the assembly, they 
Legal aspects of the manners of holding shareholders' assemblies...

were all able to submit written questions and receive real-time answers without restrictions. (Man Group, 2020, p. 7-8)

The realization of the shareholders' rights at the assembly in no way implies personal presence of the shareholder, but the possibility is left for the shareholder to authorize with letter of attorney another natural or legal person as his/her attorney in fact at an assembly of the company, which will participate and vote at the session of the assembly on his/her behalf. The shareholder must inform the joint stock company in writing about the appointment of his/her attorney in fact at a session of the company's shareholders' assembly. When authorizing representatives in writing at a company whose shares are listed on a stock exchange and at a company with special reporting obligations, the shareholders may authorize an attorney in fact at a session of the assembly by giving a letter of attorney in writing without the obligation to certify the letter of attorney with a notary. A shareholder who fails to notify the company of the letter of attorney will be deemed not to have given the letter of attorney. The second manner of authorizing attorneys in fact in the companies whose shares are listed on the stock exchange and in the companies with special reporting obligations is done electronically. The shareholders of these companies have two more advantages, compared to other joint stock companies: to authorize attorneys in fact electronically and/or to instruct authorized attorneys in fact to vote electronically. In order for companies to be able to use this opportunity, they must meet one important condition. They must provide shareholders with the use of an electronic system through which shareholders can register, authorize their attorneys in fact and instruct them to vote at a session of the company's shareholders' assembly.

The corporate governance framework should protect and facilitate the exercise of shareholders' rights and ensure equal treatment of all shareholders, including minority and foreign shareholders, whether operating under normal conditions or in the context of the Covid-19 pandemic. (Paine, 2020) Also, all shareholders should have the opportunity to receive effective primary protection in case of the violation of their rights. This area identifies the basic rights of shareholders, including the right to information and participation through the shareholders' assembly in making key decisions for the company. Accordingly, there is a need for increased insistence on the use of new rules and opportunities in this area that relate to the use of information technology in the holding of shareholders' assemblies. (Norton Rose Fulbright, 2020)

\section{Conclusion}

The unique circumstances caused by the Covid-19 pandemic impose obligations on joint stock companies to organize shareholders' assemblies by restructuring their traditional arrangements. Analyzed from the aspect of the Macedonian joint stock companies, the restructuring of the organization of the assemblies is characteristic only for a small number of them. What the Covid19 pandemic undoubtedly imposes is the need for quality digitalization of the daily functioning of all social actors. Business subjects, and especially joint 
stock companies guided by market competitive strategies, can in no way avoid the growing need for digitalization in their operations. This implies digitalization in the organization of shareholders' assemblies.

One of the modalities of organization of shareholders' assemblies is the organization of an electronic assembly, i.e. a full virtual shareholders' assembly. A full virtual shareholder assembly is usually achieved by using one, or a combination of several methods, such as web conferencing or conference calls where electronic voting is possible, while the program and organization of the assemblies are conducted in the same manner as when maintained with physical presence. (The National Law Review, 2021) Regarding the organization of fully virtual shareholders' assemblies, there are divided opinions among the stakeholders of the companies. They move from the conclusion that now is the time to change the traditional approach of the organization, which is no longer relevant and that a revolution is needed in the organization of assemblies on the one hand. On the other hand, there are stakeholders who remain convinced that assemblies should be organized solely in person. A well-organized and conducted virtual shareholders' assembly can enable increased participation of shareholders, and reduce costs for its organization. Shareholder benefits are generally associated with time savings and travel costs. The opportunity to attend the assembly virtually rather than to travel to it is appealing to many shareholders. Especially for global companies that have shareholders located in countries around the world, the virtual shareholders' assembly allows these shareholders to attend the meeting, which in most cases would not be practical to attend in person.

In order to facilitate the transition from a traditional manner of organizing shareholders' assemblies with physical presence in virtual shareholders' assemblies, it is necessary to use the possibility of organizing hybrid assemblies. Hybrid shareholders' assemblies are assemblies that allow shareholders to attend either in person or virtually, offering additional flexibility and the ability to apply in different manners, depending on the approach that best suits individual joint stock companies and their shareholder base. (Financial Reporting Council, 2020, p. 14) A hybrid organized shareholder assembly can be an assembly where a small number of shareholders gather at a location with a physical presence, with most shareholders joining and/or voting remotely, and the proceedings during the meeting are simultaneously broadcast via webcast.

Having in mind the manner of organizing the shareholders' assemblies during the Covid-19 pandemic, the general conclusion is that the Macedonian joint stock companies, after the further relaxing of the measures for social distance, will continue to support the physical presence at the annual assemblies. However, the opportunities for utilization of informationtechnological achievements and introduction of digitalization in the holding of shareholders' assemblies should not be left out. Holding assemblies with physical presence, at least in the near future, can provide joint stock companies and shareholders the opportunity to get acquainted with technological options. Concerns are raised that hybrid assemblies require dual resources, resources for 
Legal aspects of the manners of holding shareholders' assemblies...

digital organization, and other resources for physically present shareholders. However, joint stock companies must strive to increase the presence of shareholders at assemblies and at the same time take into account the fact that many modern shareholders choose to attend and exercise their rights digitally.

\section{References}

\section{Books and articles}

Gelter, M. \& Puaschunder, J. M. (2021). COVID-19 and Comparative Corporate Governance. European Corporate Governance Institute Law Working Paper, 563 (2021), 1-68.

Renneboog, L. \& Szilagyi, P. (2013). Shareholder engagement at European general meetings. In M., Belcredi \& G., Ferrarini (Ed.). Boards and Shareholders in European Listed Companies: Facts, context and postcrisis reforms (pp. 315-365). New York: Cambridge University Press.

Renneboog, L. \& Szilagyi, P. (2013). Shareholder engagement at European general meetings. In M., Belcredi \& G., Ferrarini (Ed.). Boards and Shareholders in European Listed Companies: Facts, context and postcrisis reforms (pp. 315-365). New York: Cambridge University Press.

Siems, M. M. (2008). Convergence in Shareholder Law. New York: Cambridge University Press.

Zattoni, A. \& Pugliese, A. (2021). Corporate Governance Research in the Wake of a Systemic Crisis: Lessons and Opportunities from the COVID- 19 Pandemic. Journal of Management Studies, 58 (5), 1405-1410.

\section{Blog post}

Norton Rose Fulbright. (2020, March). COVID-19: What does this mean for AGMs?

https://www.nortonrosefulbright.com/en/knowledge/publications/316 de106/covid-19-what-does-this-mean-for-agms (15.09.2021)

Kucera, W., Simala, J., \& Noreuil, A. (2020, April 29). COVID-19 and Corporate Governance: Key Issues for Public Company Directors. Harvard Law School Forum on Corporate Governance. Retrieved from: https://corpgov.law.harvard.edu/2020/04/29/covid-19-andcorporate-governance-key-issues-for-public-company-directors/ (15.09.2021)

Paine, L. S. (2020, October 06). Covid-19 Is Rewriting the Rules of Corporate Governance. Harvard Business Review. Retrieved from: https://hbr.org/2020/10/covid-19-is-rewriting-the-rules-of-corporategovernance (15.09.2021)

The National Law Review. (2021, March 17). Preparing for Your 2021 AGM and Reporting Season - What Should Be on the Agenda? Retrieved from: https://www.natlawreview.com/article/preparing-your-2021agm-and-reporting-season-what-should-be-agenda (15.09.2021) 


\section{Internet sources}

European Union, European Commission. (2020). Commission Staff Working Document: North Macedonia 2020 Report. Retrieved from: https://op.europa.eu/en/publication-detail/-/publication/f5d36c0908ad-11eb-a511-01aa75ed71a1/language-en (15.09.2021)

Financial Reporting Council. (2020). Corporate Governance AGMs: An Opportunity for Change. London: The Financial Reporting Council Limited. Retrieved from: https://www.frc.org.uk/getattachment/48c4ee08-b7be-4b7c-8f19bcaf3d44e441/Corporate-Governance-AGM.pdf (15.09.2021)

Macedonian Stock Exchange Inc. Skopje. (2014). Listing Rules. Retrieved from: http://www.mse.mk (15.09.2021)

Man Group plc. (2020). Notice of 2020 Annual General Meeting. London: Man Group plc. Retrieved from: https://www.man.com/document-archive (15.09.2021)

Marks and Spencer Group plc. (2020). Annual Report \& Financial Statements 2020. London: Marks and Spencer Group plc. Retrieved from: https://corporate.marksandspencer.com/investors/reports-results-andpresentations (15.09.2021)

OECD. (2020). National corporate governance related initiatives during the Covid-19 crisis. Paris: OECD Publishing. Retrieved from: https://www.oecd.org/corporate/National-corporate-governancerelated-initiatives-during-the-covid-19-crisis.pdf (15.09.2021)

Securities and Exchange Commission. (2020). Announcement to the Public. Retrieved from: https://www.sec.gov.mk/Vesti-govoriintervjua/Soopshtenie-do-javnosta (15.09.2021)

\section{European Union Legislation}

Directive 2007/36. The exercise of certain rights of shareholders in listed companies. European Parliament, Council of the European Union. Retrieved from: https://eur-lex.europa.eu/legalcontent/EN/TXT/?uri=celex\%3A32007L0036 (15.09.2021)

\section{National Legislation}

Law on Securities. (Official Gazette of the Republic of North Macedonia, no. 95/05, 25/07, 7/08, 57/10, 135/11, 13/13, 188/13, 43/14, 15/15, 154/15, 23/16, 83/18, 31/20). (Authors, Trans.).

Law on Trade Companies. (Official Gazette of the Republic of North Macedonia, no. 28/04, 84/05, 25/07, 87/08, 42/10, 48/10, 24/11, $166 / 12,70 / 13,119 / 13,120 / 13,187 / 13,38 / 14,41 / 14,138 / 14,88 / 15$, 192/15, 6/16, 30/16, 61/16, 64/18, 120/18, 290/20). (Authors, Trans.). 